\title{
Growth performance, carcass and meat quality of rabbits fed mistletoe leaf meal diet
}

\author{
I.E. Iso ${ }^{1}$ and O.O.O. Kennedy $*^{2}$
}

${ }^{1}$ Department of Animal Science, Cross River University of Technology, Obubra Campus; ${ }^{2}$ Department of Animal Science, University of Calabar, Calabar, PMB 1115, Cross River State, Nigeria.

*Corresponding author: oluwatosin.kennedyoko@gmail.com

Journal of Livestock Science (ISSN online 2277-6214) 12: 220-228

Received on 23/3/21; Accepted on 24/6/21; Published on 12/7/21

doi. 10.33259/JLivestSci.2021.220-228

\begin{abstract}
The study evaluated the effect of dietary mistletoe leaf (Viscum album) meal (MLM) on the growth, carcass and meat quality of rabbits. Forty-eight, New Zealand White x Chinchilla weaned rabbits (28d old, weighing 695g) were assigned to four groups ( $n=12$ per group) and subdivided into three replicates of four rabbits each. The basal (control - treatment 1) diet was formulated to contain $18 \%$ C.P and $2800 \mathrm{kcal} / \mathrm{kg}$ ME while MLM was included at 5, 10 and $15 \%$ into the basal diet to constitute treatments 2, 3 and 4, respectively. All rabbits were fed ad libitum throughout the 63 days of experiment. Growth parameters were measured weekly and at day 63, six rabbits were randomly picked per treatment for carcass evaluation. Data were subjected to the one-way ANOVA and significant means separated using the Tukey's comparison test. Result indicated that average final body weight $(1699.45-2231.12 \mathrm{~g})$, daily weight gain $(15.94-24.38 \mathrm{~g} / \mathrm{d})$, feed conversion ratio $(0.99-1.46)$, empty body weight $(1930-2050.82 \mathrm{~g})$, kidney weight $(6.75-8.45 \mathrm{~g} / \mathrm{kg})$, cold carcass yield $(61.55-65.44 \%)$ and kidney fat $(10.25-13.50)$ were significantly $(\mathrm{P}<0.05)$ different between treatments. Other growth, carcass and meat qualities did not differ $(\mathrm{P}>0.05)$ between rabbits fed mistletoe leaf diets. Significant improvements were observed in rabbit fed MLM diet especially on their daily weight gain, feed conversion ratio, carcass yield and kidney fat. This study indicated that mistletoe leaf meal is a good feed source for rabbit production. It is therefore recommended that for improved growth, carcass and meat quality, up to $15 \%$ mistletoe leaf meal should be included in rabbit diets.
\end{abstract}

Key words: Mistletoe plant; Growth rate; Carcass yield; Meat; Texture; Colour; Rabbit 


\section{Introduction}

There is increasing consumers' preference for healthy, nutritious and safe animal products which are easily digestible, rich in protein but contain low lipid and cholesterol contents (Simonová et al., 2010). In Nigeria, microlivestock production including rabbit, quail and snail farming is gaining popularity as the ideal animal protein sources with numerous health benefits and good returns on investment (Olawoyin and Iso, 2007; Agiang et al., 2009; Ozung et al., 2017).

According to Fasuyi (2005), rabbit production is one of the cheapest means of providing readily available animal protein for the teeming Nigerian populace. This is due to its relatively lower cost of production, prolificacy, ability to convert forages not competed for by human into rich animal protein and ease of management (Cardinali et al., 2015; Dalle Zotte et al., 2016; Ozung et al., 2017). Nutritionally, rabbit meat is reported to have high energy value of $427-849 \mathrm{~kJ} / 100 \mathrm{~g}$ (fresh meat), crude protein content of $20-21 \%, 60 \%$ of oleic and linoleic as unsaturated fatty acids, moderate values for potassium, phosphorus and magnesium with low lipids, cholesterol, and sodium contents (Hermida et al. 2006; Simonová et al., 2010; Para et al., 2015; Zepeda-Bastida et al., 2019). These qualities make rabbit meat a highly digestible choice meat and thus recommended for consumption for all age ranges including people with cardiovascular illnesses (Hu and Willett 2002).

In recent times, researches are now focused on exploring natural plant materials including; forages, vegetables, shrubs and tree leaves that are available all the year round to serves as feed and alternative antibiotics in many farm animals due to their numerous antimicrobial properties (Simonová et al. 2010; FAO, 2011). The report of Elwan et al. (2019) encouraged the use of nutritional antioxidants for improved rabbit production. Thus, several plant species are now incorporated into feeding regimes of fattening rabbits as feed supplements for improved productivity and meat quality (Koné et al., 2016; Dabbou et al., 2017; ZepedaBastida et al., 2019). One of such plants is the mistletoe leaf with known antimicrobial and phytogenic properties (Tizhe et al., 2016; Njoya et al., 2018).

Mistletoes are hemi-parasites that grow on tree trunk branches to photosynthesize and bear green leaves while their roots - "haustoria" penetrate into their host tree for water and mineral nutrients uptake (Ogunmefun et al., 2015). They grow on many economic tree crops such as sheabutter, neem, citrus, cocoa, rubber, kolanut, coffee, bush mango and guava (Ogunmefun et al., 2015; Njoya et al., 2018; Umarudeen, and Magaji, 2020).

In Nigeria, several mistletoe species including; Viscum album, Loranthus bengwensis and Tapinanthus dodoneifolius are known to be used in the treatments of diabetics, skin diseases, prostate cancer and bacterial infections in farm animals (Umarudeen and Magaji, 2020). There is a dearth of information on their use as feed supplement in rabbit diets, thus this study evaluated the effect of dietary mistletoe leaf meal on the growth, carcass and meat quality of rabbits.

\section{Materials and Methods}

This study was carried out at the experimental rabbit station of the Teaching and Research Farm, University of Calabar, Calabar, Nigeria. Calabar is located in the South - south region of the country at latitude 4'75N and longitude $8^{\prime} 190 \mathrm{E}$ with an annual rainfall of $1260-1280 \mathrm{~mm}$, average temperature of $25-300 \mathrm{C}$, relative humidity of $60-80 \%$ with an elevation of $99 \mathrm{~m}$ above sea level (NMA, 2020).

The experimental protocol was reviewed and approved by the Animal Ethics Committee of University of Calabar, Nigeria and the rabbits were cared for according to the NIH standard guidelines for the care and use of laboratory animals.

The mistletoe (Viscum album) plant was obtained from African pear trees within the University farm in Calabar, Cross River State of Nigeria. The plants were transported to the Nutrition Laboratory and the leaves of mistletoe were sorted and air-dried at room temperature for $120 \mathrm{hr}$. The dried leaves were ground using a miller (DIETZ, 7311 Dettingen-Teck, West Germany) of $0.5 \mathrm{~mm}$ sieve to form mistletoe leaf meal (MLM).

MLM was stored in an air-tight plastic container until required for further analyses. The proximate analysis on the chemical composition (Table 1) of MLM was determined (crude protein - 8.3; ash - 5.93; ether extract - 8.3; crude fiber - 33.1; neutral detergent fiber - 60.43; and acid detergent fiber - 24.84) according to the AOAC (2010) standard methods. The basal (control) diet was formulated from local feed ingredients to contain $18 \%$ crude protein and $2800 \mathrm{kcal} / \mathrm{kg}$ metabolizable energy (Table 2) to meet or exceed the DeBlas and Mateos (2010) and NRC (2012) nutrient requirements. The mistletoe leaf meal was added (5,10 and 15\%) into the basal diet to constitute Treatments 2, 3 and 4, respectively.

Forty-eight weaned male rabbits ( $28 \mathrm{~d}$ ) of the New Zealand white and chinchilla crosses with average weight of $524.16 \pm 13.40 \mathrm{~g}$ were randomly assigned to the four dietary groups (of three replicates of four rabbits each) in a completely randomized design. Individual rabbit was housed in hutch adapted with manual feeder and drinker. Pelletized feed and clean water were offered ad libitum throughout the $63 \mathrm{~d}$ of experiment. Rabbits 
were weighed at $\mathrm{d} 7,14,21,28,35,42,49,56$ and 63 of age and feed intake was measured throughout these periods. Weekly weight gain and feed conversion ratio (FCR) were also calculated. Death observed per treatment was recorded as it occurred. At d 63, six rabbits were randomly picked per treatments and slaughtered at the meat unit of the University of Calabar Research Laboratory. They were stunned prior to jugular vein dislocation and processed according to the methods described by Zepeda-Bastida et al. (2019). Each carcass was dissected to obtain hot carcass, heart, liver, lungs, spleen, kidney, digestive system, bladder, skin and the eviscerated weight (was calculated after the removal of the gastrointestinal contents). All sections were individually weighed and expressed as percentages of live weight. Carcasses were then stored in refrigeration at $4{ }^{\circ} \mathrm{C}$ for $24 \mathrm{~h}$. Post refrigeration ( $24 \mathrm{~h}$ ), each carcass was sectioned into cut-up parts as described by Blasco et al. (1993). The head was sectioned at the atlas region, forequarter (at the sixth and seventh ribs), thoracic cage (at the last rib) and the loin was sectioned from the sixth and seventh lumbar vertebrae by dissecting the abdominal wall transversally to the vertebral column, thereafter excising the foreleg. Cut-up parts were individually weighed.

Loin samples were collected from carcasses of each treatment for meat colour evaluation with the aid a portable colorimeter i-Lab S560 (Microptix, Wilton, Maine, USA). Values for each colour was read using the American Meat Science Association meat color measurement guidelines (AMSA, 2012) as indicated by L* for lightness, $\mathrm{a}^{*}$ - redness, and $\mathrm{b}^{*}$ - yellowness. A pH meter (Hanna model HI99163, Hanna instruments, ClujNapoca, Romania) was used in determining the ${ }_{\mathrm{p}} \mathrm{H}$ value of the meat. Water holding capacity was measured by the Honikel (1987) method. In the determination of meat cooking losses, loin samples were put into a plastic bag, cooked at $80^{\circ} \mathrm{C}$ for 45 mins, cooled at room temperature then weighed. Differences in weights before and after cooking was expressed as a percentage to form the cooking loss values.

A portion of the cooled meat was used for texture profile analysis using the Brookfield model CT3 analyzer (Brookfield, Middleboro, MA, USA) according to method highlighted by Zepeda-Bastida et al. (2019). Six cubes (of $1 \mathrm{~cm}$ each side) of loin were sectioned parallel to muscle fibers, with the texture analyzer set to compress $50 \%$ of the sample at right angle to the muscle fiber with the aid of a TA3/1000 probe and TA-BTKIT base. For meat composition, procedures of Yalcin et al. (2006) were adhered to. Samples were collected from the breast muscle of four (4) carcasses per treatment, wrapped individually in polythene bags and immediately placed in a freezer $\left(-20^{\circ} \mathrm{C}\right)$ for $24 \mathrm{~h}$, thereafter thawed in a refrigerator $\left(+4^{\circ} \mathrm{C}\right)$ in readiness for chemical analysis. Samples were analyzed for moisture, fat, protein and ash content (AOAC, 2000). Energy value was obtained by the Atwater System (Paul and Southgate, 1985). Calcium and magnesium contents were analyzed using an atomic absorption spectrophometer (AAS), potassium and sodium (flame photometer) while that of phosphorus was analyzed with a colorimeter using vanadomolybdate (yellow) method and spectrophometer (model - spectro Ur VIS RS spectrophotometer vu - 2500).

Data were analyzed using the General Lineal Model procedure of GENSTAT (2012) software package. The statistical model used was:

$$
\begin{aligned}
& Y i j=\mu+\beta i+\varepsilon i j, \\
& \text { Where; Yij = dependent variable, } \\
& \mu=\text { overall mean of the variable, } \\
& \beta i=\text { fixed effect of } i \text {-nth rabbit of the treatment, } \\
& \varepsilon i j=\text { experimental error associated with the observation Yij. }
\end{aligned}
$$

\section{Results}

Table 1 showed that mistletoe leaf meal (MLM) has high crude protein (18.28\%), ash (6.03\%) with very low amounts of crude fibre $(4.02 \%)$ and ether extract $(0.20 \%)$. The mineral composition of mistletoe leaf indicated higher concentration of calcium $(28.40 \%)$ followed by magnesium $(19.00 \%)$, iron $(17.00 \%)$, potassium $(15.30 \%)$, sodium $(6.50 \%)$ with the least concentration in cobalt $(0.02 \%)$ (Table 1$)$.

Table 3 presents the growth response of rabbits to dietary mistletoe leaf meal. Final weight, daily weight gain and feed conversion ratio were significantly $(\mathrm{P}<0.05)$ influenced by dietary treatments. At increasing inclusion level of MLM, improved growth rate were observed in rabbits. Final body weight, average daily gain and feed conversion ratio had improved $(\mathrm{P}<0.05)$ by $5.22-31.29 \%, 8.78-52.95 \%$ and $8.22-$ $32.19 \%$, respectively.

Table 4 Indicated that apart from empty body weight, cold carcass yield, kidneys and kidney fats, there were no significant $(\mathrm{P}>0.05)$ differences in the carcass quality of rabbits fed varying dietary mistletoe leaf meal. At increasing inclusion levels of mistletoe leaf meal empty body weight, carcass yield and kidney weights had increased $(\mathrm{P}<0.05)$ by $0.79-6.26 \%, 2.11-6.32 \%$ and $1.93-25.19 \%$, respectively with a $14.44-24.07 \%$ reduction in kidney fat content. 
Table 1. Chemical composition of mistletoe leaf meal (MLM) on Dry matter basis

\begin{tabular}{|l|c|}
\hline Nutrients & Percentage (\%) \\
\hline Moisture & 16.85 \\
\hline Dry matter (\%) & 83.15 \\
\hline Crude protein (\%CP) & 18.28 \\
\hline Crude fibre (\% CF) & 4.02 \\
\hline Ash (\% DM) & 6.03 \\
\hline Ether Extract (\% EE) & 0.20 \\
\hline Nitrogen free extract (\%NFE) & 54.62 \\
\hline Minerals composition (\%) & \\
\hline Calcium & 28.40 \\
\hline Magnesium & 19.00 \\
\hline Potassium & 15.30 \\
\hline Copper & 0.80 \\
\hline Sodium & 6.50 \\
\hline Iron & 17.00 \\
\hline Zinc & 0.83 \\
\hline Lead & 0.05 \\
\hline Cobalt & 0.02 \\
\hline Phosphorus & 12.10 \\
\hline
\end{tabular}

Values are means of three replicates

Table 2. Composition of experimental rabbit diets (\%)

\begin{tabular}{|c|c|c|c|c|}
\hline Ingredient, \% & $\begin{array}{c}\text { 0\% MLM } \\
\text { (Control) }\end{array}$ & $\begin{array}{c}5 \% \\
\text { MLM }\end{array}$ & $\begin{array}{c}10 \% \\
\text { MLM }\end{array}$ & $\begin{array}{c}15 \% \\
\text { MLM }\end{array}$ \\
\hline Maize & 49.99 & 44.99 & 39.99 & 34.99 \\
\hline Soybean meal & 31.01 & 31.01 & 31.01 & 31.01 \\
\hline Rice bran & 5.00 & 5.00 & 5.00 & 5.00 \\
\hline MLM (Mistletoe leaf meal) & 0.00 & 5.00 & 10.00 & 15.00 \\
\hline Wheat offal & 10.00 & 10.00 & 10.00 & 10.00 \\
\hline Bone meal & 3.00 & 3.00 & 3.00 & 3.00 \\
\hline Salt & 0.50 & 0.50 & 0.50 & 0.50 \\
\hline *Premix & 0.50 & 0.50 & 0.50 & 0.50 \\
\hline Total & 100.00 & 100.00 & 100.00 & 100.00 \\
\hline \multicolumn{5}{|l|}{ Calculated value } \\
\hline$\%$ Crude protein & 18.00 & 18.24 & 18.28 & 18.39 \\
\hline Metabolizable energy, kcal/kg & 2800.00 & 2800.37 & 2800.45 & 2800.63 \\
\hline \multicolumn{5}{|l|}{ Analyzed value } \\
\hline$\%$ Crude protein & 18.21 & 18.22 & 18.24 & 18.26 \\
\hline$\%$ Crude fibre & 8.61 & 8.72 & 8.77 & 9.01 \\
\hline$\%$ Ether extract & 2.86 & 2.89 & 2.84 & 2.90 \\
\hline
\end{tabular}

*Vitamin BCP (premix; 0.25\% vitamins and Trace elements), each 2.5kg supplied the following: Vitamin A 10,000,000 I.U, Vitamin D 2,000,000 I.U, Vitamin E 20,000I.U, Vitamin K 2,250mgr, Thiamine 1,750mgr, Riboflavin B2 5,000mgr, Pyridoxine B6 2,750 mgr, Niacin 27,500 mgr, Vitamin B1215 mgr, Pantothenic acid 7,500 mgr, Biotin $50 \mathrm{mgr}$, Cholin chloride 400gr, Antioxidant 125 gr, Manganese 80 gr, Zinc $50 \mathrm{gr}$, Iron $20 \mathrm{gr}$, Copper $5 \mathrm{gr}$, Iodine $1.20 \mathrm{gr}$, Selenium $200 \mathrm{gr}$, Cobalt $200 \mathrm{gr}$

Table 3. Effect of mistletoe leaf meal (MLM) inclusion levels on rabbit performance

\begin{tabular}{|c|c|c|c|c|c|}
\hline Parameter & $\begin{array}{c}\text { 0\% } \\
\text { MLM }\end{array}$ & $\begin{array}{c}5 \% \\
\text { MLM }\end{array}$ & $\begin{array}{l}10 \% \\
\text { MLM }\end{array}$ & $\begin{array}{l}15 \% \\
\text { MLM }\end{array}$ & SEM \\
\hline Initial weight $(\mathrm{g})$ & 695.00 & 695.00 & 695.00 & 695.00 & 0.00 \\
\hline Final weight $(\mathrm{g})$ & $1699.45^{\mathrm{c}}$ & $1788.10^{\mathrm{bc}}$ & $2197.21^{\mathrm{a}}$ & $2231.12^{\mathrm{a}}$ & 0.04 \\
\hline Total weight gain $(\mathrm{g})$ & $1004.45^{\mathrm{b}}$ & $1093.10^{\mathrm{ab}}$ & $1502.21^{\mathrm{a}}$ & $1536.12^{\mathrm{a}}$ & 0.05 \\
\hline Mean weekly body weight gain (g/week/rabbit) kcal/kg & $111.61^{\mathrm{c}}$ & $121.46^{\mathrm{bc}}$ & $166.91^{\mathrm{ab}}$ & $170.68^{\mathrm{a}}$ & 0.04 \\
\hline Mean daily weight gain $(\mathrm{g} / \mathrm{d} / \mathrm{rabbit})$ & $15.94^{\mathrm{c}}$ & $17.35^{\mathrm{bc}}$ & $23.85^{\mathrm{a}}$ & $24.38^{\mathrm{a}}$ & 0.03 \\
\hline Average weekly feed intake (g/week/rabbit) & 163.00 & 162.86 & 164.86 & 173.29 & 0.06 \\
\hline Average daily feed intake (g/d/rabbit) & 23.29 & 23.27 & 23.55 & 24.76 & 0.06 \\
\hline Feed conversion ratio & $1.46^{\mathrm{a}}$ & $1.34^{\mathrm{a}}$ & $0.99^{\mathrm{b}}$ & $1.02^{\mathrm{ab}}$ & 0.02 \\
\hline Mortality (\%) & 2.25 & 2.00 & 1.50 & 1.50 & 0.07 \\
\hline
\end{tabular}

SEM = Standard error of means; $a, b$ and $c=$ means with different superscripts on the same row differ $(\mathrm{P}<0.05)$ significantly 
Table 4. Carcass characteristics of rabbits fed mistletoe leaf meal

\begin{tabular}{|l|c|c|c|c|c|}
\hline Cut-up part (\%LW) & $\mathbf{0 \%}$ MLM & $\mathbf{5 \% M L M}$ & $\mathbf{1 0 \%}$ MLM & $\mathbf{1 5 \%}_{\mathbf{M L M}}$ & SEM \\
\hline Empty body weight $(\mathrm{g})$ & $1930.00^{\mathrm{b}}$ & $1945.25^{\mathrm{ab}}$ & $1975.65^{\mathrm{ab}}$ & $2050.82^{\mathrm{a}}$ & 0.05 \\
\hline Dressing percentage (\%) & 59.50 & 60.06 & 60.12 & 60.19 & 0.15 \\
\hline Visceral $(\mathrm{g} / \mathrm{kg})$ & 245.25 & 249.95 & 255.63 & 260.45 & 0.28 \\
\hline Full gastrointestinal tract weight $(\mathrm{g})$ & 183.50 & 185.75 & 188.88 & 190.25 & 0.26 \\
\hline Full bladder $(\mathrm{g} / \mathrm{kg})$ & 5.33 & 5.28 & 4.95 & 4.70 & 0.26 \\
\hline Heart $(\mathrm{g} / \mathrm{kg})$ & 2.80 & 2.85 & 2.99 & 3.10 & 0.17 \\
\hline Lungs $(\mathrm{g} / \mathrm{kg})$ & 7.75 & 7.52 & 6.95 & 6.78 & 0.27 \\
\hline Spleen $(\mathrm{g} / \mathrm{kg})$ & 0.60 & 0.58 & 0.55 & 0.50 & 0.06 \\
\hline Liver $(\mathrm{g} / \mathrm{kg})$ & 42.50 & 42.55 & 44.24 & 45.00 & 0.18 \\
\hline Kidneys $(\mathrm{g} / \mathrm{kg})$ & $6.75^{\mathrm{b}}$ & $6.88^{\mathrm{ab}}$ & $7.43^{\mathrm{ab}}$ & $8.45^{\mathrm{a}}$ & 0.04 \\
\hline Empty GIT $(\mathrm{g})$ & 88.52 & 90.92 & 91.25 & 92.55 & 0.12 \\
\hline Empty Bladder $(\mathrm{g} / \mathrm{kg})$ & 2.00 & 1.95 & 1.88 & 1.85 & 0.11 \\
\hline Cold carcass yield $(\%)$ & $61.55^{\mathrm{b}}$ & $62.85^{\mathrm{ab}}$ & $63.95^{\mathrm{a}}$ & $65.44^{\mathrm{a}}$ & 0.04 \\
\hline Kidney fat $(\mathrm{g} / \mathrm{kg})$ & $13.50^{\mathrm{a}}$ & $11.55^{\mathrm{b}}$ & $10.65^{\mathrm{bc}}$ & $10.25^{\mathrm{c}}$ & 0.03 \\
\hline Scapular fat weight $(\mathrm{g} / \mathrm{kg})$ & 4.95 & 4.95 & 4.97 & 5.00 & 0.08 \\
\hline Head $(\mathrm{g} / \mathrm{kg})$ & 62.55 & 62.37 & 61.99 & 61.45 & 0.11 \\
\hline Fore part weight $(\mathrm{g} / \mathrm{kg})$ & 149.55 & 152.23 & 152.45 & 155.20 & 0.36 \\
\hline Intermediate part weight $(\mathrm{g} / \mathrm{kg})$ & 62.85 & 63.56 & 64.55 & 65.10 & 0.25 \\
\hline Hind part weight $(\mathrm{g} / \mathrm{kg})$ & 115.62 & 115.45 & 114.96 & 113.55 & 0.15 \\
\hline
\end{tabular}

a, b and c - Different superscripts within rows indicate significant difference between treatments using Tukey's test $(\mathrm{P}<0.05)$.

Table 5. Meat quality of rabbits fed mistletoe leaf meal diets

\begin{tabular}{|l|c|c|c|c|c|}
\hline \multicolumn{1}{|c|}{ Parameter (\%) } & 0\% MLM & 5\% MLM & 10\% MLM & 15\% MLM & SEM \\
\hline Body length (cm) & 30.50 & 35.25 & 36.75 & 35.80 & 4.21 \\
\hline Legs (g) & 205.45 & 208.15 & 211.15 & 215.55 & 2.25 \\
\hline Meat (\% Leg wt) & 69.25 & 70.50 & 71.06 & 71.10 & 1.22 \\
\hline Bone (\% Leg wt) & 22.50 & 21.75 & 21.52 & 21.49 & 0.25 \\
\hline Meat:Bone ratio & 3.08 & 3.23 & 3.30 & 3.31 & 0.08 \\
\hline Fat (\% Leg wt) & 8.25 & 7.75 & 7.42 & 7.41 & 0.14 \\
\hline pH & 5.85 & 5.87 & 5.87 & 5.91 & 0.18 \\
\hline Water holding capacity (\%) & 23.05 & 22.91 & 22.95 & 23.19 & 0.11 \\
\hline L $^{*}$ & 58.50 & 58.80 & 58.95 & 60.05 & 0.10 \\
\hline $\mathrm{a}^{*}$ & 0.55 & 0.55 & 0.62 & 0.63 & 0.06 \\
\hline $\mathrm{b}^{*}$ & 10.55 & 11.25 & 11.45 & 11.75 & 0.07 \\
\hline Cooking loss (\%) & 18.55 & 18.55 & 18.65 & 18.55 & 0.07 \\
\hline Hardness (N) & 7.67 & 7.55 & 7.65 & 7.60 & 0.08 \\
\hline
\end{tabular}

a,b - Different superscripts within rows indicate significant differences among treatments using Tukey's test $(\mathrm{P}<0.05) \mathrm{L}^{*}$ for lightness, $\mathrm{a}^{*}$ redness, and $b^{*}$ - yellowness

Table 6. Chemical composition of rabbit meat (\%)

\begin{tabular}{|l|c|c|c|c|c|}
\hline \multicolumn{1}{|c|}{ Nutrient (\%) } & 0\% MLM & 5\% MLM & $\mathbf{1 0 \%}$ MLM & 15\% MLM & SEM \\
\hline Moisture content & 70.90 & 70.80 & 70.90 & 72.10 & 0.08 \\
\hline Crude protein & 78.00 & 79.12 & 79.15 & 79.20 & 0.06 \\
\hline Ether Extract & $8.25^{\mathrm{a}}$ & $6.75^{\mathrm{bc}}$ & $6.75^{\mathrm{bb}}$ & $6.40^{\mathrm{c}}$ & 0.04 \\
\hline Ash & 4.00 & 3.74 & 3.75 & 3.80 & 0.06 \\
\hline Nitrogen free extract & 9.75 & 10.39 & 10.35 & 10.60 & 0.11 \\
\hline Mineral content g/100g & & & & \\
\hline Calcium & 0.16 & 0.24 & 0.24 & 0.24 & 0.07 \\
\hline Phosphorus & 0.30 & 0.34 & 0.34 & 0.33 & 0.07 \\
\hline Sodium & 0.03 & 0.04 & 0.04 & 0.04 & 0.07 \\
\hline Magnesium & 0.38 & 0.36 & 0.36 & 0.38 & 0.06 \\
\hline Potassium & 1.17 & 1.14 & 1.14 & 1.16 & 0.11 \\
\hline
\end{tabular}

a, b and c - Different superscripts within rows indicate significant difference between treatments using Tukey's test $(\mathrm{P}<0.05)$.

Compared to the control, meat weight was slightly higher $(\mathrm{P}>0.05)$ in the rabbits fed mistletoe leaf meal with lower dissectible fat (Table 5). Meat: bone ratio also increased (from 3.08 to 3.31) at higher mistletoe inclusions indicative of an increased meat yield following mistletoe inclusion. Table 6 presented the effects of mistletoe leaf on the meat composition of rabbit. Apart from ether extract, there were no significant $(\mathrm{P}>0.05)$ of dietary treatments on the composition of rabbit meat. The inclusion of mistletoe leaf in the diet reduced $((\mathrm{P}<0.05)$ fat in the meat indicating good quality product. 


\section{Discussion}

The values for the chemical compositon of mitletoe obtained in this study were consistent with results of Njoya et al. (2018) for ether extract $(0.2 \%)$ and crude fibre $(4.27 \%)$ in the Tapinanthus preussii leaves with higher crude protein $(14.7 \%)$ and NFE $(69.3 \%)$ but lower ash (3.6\%) contents. Variations in results could be due to the variety of plants host and method of analyses. Moyosore et al. (2013) had reported higher ether extract $(9.65 \%)$ in Tapinanthus bangwensis ethanolic extract. The high crude proteins are essential for the synthesis of body tissues and regulatory substances such as enzymes and hormones (Vaughan and Judd, 2003). This result indicated that mistletoe leaf meal (MLM) is a good protein and energy sources, therefore, it could serve as a feed supplements for humans and livestock compared to some leafy vegetables such as pumpkin leaves, taro leaves, mushrooms and tomatoes (FAO, 2006).

The mineral concentrations in plants have significant defense mechanisms against various human disease conditions (Ceyik et al., 2003). The mineral concentrations in the present study fell with ranges reported by Njoya et al. (2018). The high concentration of calcium in the leaf of mistletoe plant suggest that it is a valuable plant because of its contribution in blood clotting, muscle contraction, bone and teeth formation/repairs and in some enzymatic metabolic processes in humans and animals (NRC, 2012).

The high value of magnesium recorded in mistletoe leaf suggest that mistletoe leaf possess ability to prevent muscle degeneration, growth retardation, alopecia, dermatitis, immunologic dysfunction, gonadal dystrophy, impaired spermatogenesis, congenital malformations and other disorders in humans and animals. Iron is an essential component in several proteins and enzymatic activities and it plays various biochemical roles in the body metabolic functions. Potassium and sodium control the electrolyte balance in the body. The high crude protein and mineral contents obtained in mistletoe leaf further explains its use in traditional medicine in the treatment of various ailments.

Results from Table 3 imply that mistletoe leaf meal improves the growth performances of rabbit probably due to its high nutritional contents leading to higher nutrient availability and digestibility. The final body weight obtained in this study was higher than the values of 1150-1625g (Abdulkadir et al., 2011) and 1400-1500g (Omoikhoje et al., 2006) for rabbits at similar ages but consistent with values reported by Njoya et al. (2018). Findings from this result are consistent with the report of Zepeda-Bastida et al. (2019) which indicated a $60 \%$ dressing percentage with no differences in the carcass quality of rabbits fed Tithonia tubaeformis weed. Anhita et al. (2016b), Cullere et al. (2016) and Molina et al. (2018) also observed no effects on rabbit carcass quality when fed fresh azolla, Silybum marianum and Amaranthus dubius, respectively. Alagawany et al. (2016) however reported improved carcass traits and meat quality in rabbits following dietary supplementation with natural plant products. Higher kidney weight was observed at increasing MLM level suggesting that mistletoe leaf could contain some bioactive compounds that affects the kidney, since the kidney is the point of detoxification of chemical substances.

This result is in line with the findings of Molina et al. (2018) who reported increased meat yield in rabbit fed amaranthus diets. North et al. (2018) noted that an increase in meat:bone ratio, maybe due to decrease in bone weight when plant additives are added to diets and thus alters bone structure. Mistletoe leaf is also incorporated in pullets (Jimoh et al., 2018) and broiler (Ologhobo et al., 2017) with improved antioxidant and growth effects.

Rabbits' $\mathrm{pH}$ values $(5.85$ - 5.91) were not affected by dietary treatments, which was consistent to previous reports when ginger powder (Mancini et al., 2018), quercetin (North et al., 2018), Amarantus dubius (Molina et al., 2018), and quebracho-chestnut tannin mix (Mancini et al., 2019) were supplemented into rabbits diets. However, Hinojosa Dávalos et al. (2013) and Cullere et al. (2016) reported increased pH values in rabbit meat fed Tithonia tubaeformis and Silybum marianum, respectively. The variations probably may due to the high amount of antioxidant compounds such as phenols and flavonoids in the plants. Hulot and Ouhayoun (1999) explained that factors such as diet, breed, pre-slaughter procedures, carcass cooling rate and muscle localization could affect $\mathrm{pH}$ of rabbit meat.

Meat colour and texture were not affected $(\mathrm{P}>0.05)$ by mistletoe leaf meal inclusion. This observation agrees with the report by Volek et al. (2018), North et al. (2018) and Koné et al.(2019) when rabbits were fed white lupin seed, quercetin and oil extract from a mix of different plants, respectively. On the other hand, Mancini et al. (2018) reported significant increase in rabbit meat colour following dietary ginger powder supplementation. The concentrations of antioxidative compounds such as phenols and flavonoids in plants are implicated for meat colour. Supplementation with plant products are reported to produce softer rabbit meat due to presence of active compounds in the plants thereby leading to an increased nutrient synthesis and assimilation. The inclusion of mistletoe leaf slightly reduced cooking loss and hardiness in rabbit meat as reported when Tithonia tubaeformis was included in rabbit diets (Zepeda-Bastida et al., 2019). Mistletoe is a parasitic plant that grows on several trees in Africa and as such, it is readily available with little or low market cost. 


\section{Conclusion}

These present findings indicated no adverse effects of mistletoe leaf meal inclusion on the growth, carcass and meat quality of rabbits thus, MLM could be used to produce low-cost feeds. Significant improvements were observed in rabbits fed MLM diets specifically on their daily weight gain, feed conversion ratio, carcass yield and kidney fat. This study indicated that mistletoe leaf meal is a good feed source for rabbit production. It is therefore recommended that for improved growth, carcass and meat quality, up to $15 \%$ mistletoe leaf meal should be included in rabbit diets.

\section{Conflict of interest}

All authors have approved the submission of this manuscript and do declare that there is no conflict of interest. The manuscript has not been published previously and is not under consideration for publication elsewhere.

\section{References}

1) Abdulkadir IE, Aliyu AB, Ibrahim MA, Audu SBD, Oyewale AO, 2011. Antioxidant activity and mineral elements profiles of Isoberlinia doka leaves from Nigeria. Australain Journal of Basic and Applied Sciences 5(12): 2507-2512.

2) Agiang EA, Eneji CA, Iso EI, Isika MA, 2009. Effects of mixed-feeding on physiological development and nutritional qualities of rabbit meat. Journal of Agriculture, Biotechnology and Ecology 2(1): 69-77.

3) Alagawany M, Ashour EA, Reda FM, 2016. Effect of dietary supplementation of garlic (Allium sativum) and turmeric (Curcuma longa) on growth performance, carcass traits, blood profile and oxidative status in growing rabbits. Annals of Animal Science 16: 489-505.

4) AMSA 2012. American Meat Science Association. 2012. Meat color measurement guidelines. Champaign, IL, USA

5) Anhita KC, Rajeshwari YB, Prabhu TM, Devarnvadagi AS, Rohith KJ, Shilpa Shree J 2016. Carcass and meat quality traits of broiler rabbits when supplement with azolla. Journal of Experimental Zoology 19: 417-420.

6) AOAC, 2010. Official methods of Analysis $18^{\text {th }}$ Edition. Association of Official Analytical Chemist, Washington. D.C.

7) Blasco A, Ouhayoun J, Masoero G, 1993. Harmonization of criteria and terminology in rabbit meat research. World Rabbit Science 1: 3-10. https://doi.org/10.4995/wrs.1993.189.

8) Cardinali R, Cullere M, Dal Bosco A, Mugnai C, Ruggeri S, Mattioli S, Castellini C, Trabalza Marinucci M, Dalle Zotte A, 2015. Oregano, rosemary and vitamin E dietary supplementation in growing rabbits: Effect on growth performance, carcass traits, bone development and meat chemical composition. Journal of Livestock Science 175: 83-89. https://doi .org/10.1016/j.livsci.2015.02.010

9) Ceyik U, Ergen E, Budak G, Karabulut A, Tiraolu E, Apaydin G, Kopya AL, (2003). Elemental Analysis of Akçaabat Tobacco and its Ash by EDXRF Spectrometry. Journal of Quantitative Spectroscopy and Radiative Transfer, 78: 409-415.

10) Cullere M, Dalle Zotte A, Celia C, Renteria-Monterrubio AL, Gerencsér Zs, Szendrő Zs, Kovács M, Kachlek ML, Matics Zs, 2016. Effect of Silybum marianum herb on the productive performance, carcass traits and meat quality of growing rabbits. Journal of Livestock Science 194:31-36. https://d i.org/10.1016/j.livsci.2016.10.012

11) Dabbou S, Renna M, Lussiana C, Gai F, Rotolo L, Kovitvadhi A, Brugiapaglia A, Helal AN, Schiavone A, Zoccarato I, Gasco L, 2017. Bilberry pomace in growing rabbit diets: effects on quality traits of hind leg meat. Italian Journal of Animal Science 16:371-379. https://doi.org/10.1080/1828051X.2017.1292413

12) Dalle Zotte A, Celia C, Szendro Zs, 2016. Herbs and spices inclusion as feedstuff or additive in growing rabbit diets and as additive in rabbit meat: a review. Journal of Livestock Science 189:82-90. https://doi.org/10.1016/j.livsci.2016.04.024

13) De Blas C, Mateos GG, 2010. Feed formulation. pp. 222 -232. In: Nutrition of the rabbit. 2nd Edition. de Blas, C. and Wiseman, J., eds. Cab International, Wallingford, UK.

14) Elwan HAM, Elnesr SS, Mohany M, Al-Rejaie SS, 2019. The effects of dietary tomato powder (Solanum lycopersicum L.) supplementation on the haematological, immunological, serum biochemical and antioxidant parameters of growing rabbits. Journal of Animal Physiololgy and Animal Nutrition 103: 534-546. https://doi.org/10.1111/jpn.13054.

15) FAO, 2006. FAO. Global forest resources assessment 2005: progress towards sustainable forest management. Forestry Paper 147. United Nations Food and Agriculture Organization (FAO), Rome. 2006. Available from, 2014: http:// www.fao.org. 
16) FAO, 2011. World livestock 2011. Livestock in food security. Food and Agriculture Organization of the United Nations Report published on $14^{\text {th }}$ December, 2011.

17) Fasuyi AO, 2005. Nutritional potentials of some tropical vegetables leaf meals: chemical characterization and functional properties African Journal of Biotechology 5(1): 49-53.

18) GENSTAT, 2012. GENSTAT 15th Edition, VSN International Ltd (VSNi). http://www.vsni.co.uk.

19) Hermida M, Gonzalez M, Miranda M, Rodríguez-Otero JL, 2006. Mineral analysis in rabbit meat from Galicia (NW Spain). Meat Sci 73: 635-639.

20) Hinojosa Dávalos J, Gutiérrez Lomelí M, Siller López F, Rodríguez Sahagún A, Morales Del Río JA, Guerrero Medina PJ, Del Toro Sánchez CL, 2013. Screening fitoquímico y capacidad ntiinflamatoria de hojas de Tithonia tubaeformis. Biotecnia 15: 53-60.

21) Honikel KO, 1987. How to measure the water-holding capacity of meat? Recommendation of standardized methods. In: Evaluation and control of meat quality in pigs. Current Topics in Veterinary Medicine and Animal Science, Vol. 38. Tarrant P. V.; Eikelenboom, G. and Monin, G., eds. Springer, Dordrecht, Germany.

22) Hu FB, Willett WC, 2002. Optimal diets for prevention of coronary heart disease. Journal of American Medical Association 288: 2569-2578.

23) Hulot F, Ouhayoun J, (1999). Muscular $\mathrm{pH}$ and related traits in rabbits: A review. World Rabbit Science 7: 15-36. https://doi.org/10.4995/wrs.1999.378.

24) Jimoh OA, Ihejirika UG, Balogun AS, Adelani SA, Okanlawon OO, 2018. Antioxidant status and serology of laying puleets fed diets supplemented with mistletoe leaf meal. Nigerian Journal of Animal Science 20(1): $52-60$.

25) Koné AP, Cinq-Mars D, Desjardins Y, Guay F, Gosselin A, Saucier L, 2016. Effects of plant extracts and essential oils as feed supplements on quality and microbial traits of rabbit meat. World Rabbit Science 24:107-119. https://doi.org/10.4995/wrs.2016.3665.

26) Koné AP, Desjardins Y, Gosselin A, Cinq-Mars D, Guay F, Saucier L, 2019. Plant extracts sand essential oil product as feed additives to control rabbit meat microbial quality. Meat Science 150: 111-121. https://doi.org/10.1016/j.meatsci.2018.12.013.

27) Mancini, S.; Secci, G.; Preziuso, G.; Parisi, G. and Paci, G. 2018. Ginger (Zingiber officinale Roscoe) powder as dietary supplementation in rabbit: life performances, carcass characteristics and meat quality. Italian Journal of Animal Science 17: 867-872.

28) Molina E, González-Redondo P, Moreno-Rojas R, Montero-Quintero K, Sánchez-Urdaneta A, 2018. Effect of the inclusion of Amaranthus dubius in diets on carcass characteristics and meat quality of fattening rabbits. Journal of Applied Animal Research 46: 218-223.

29) Moyosore, O., Nwoke, S. C., Imaga, N. A., Magbagdeola, A. O., Ebuehi, A. O., Okafor, O. A. (2013). Preliminary Investigation of The Nutritional Qualities, Phytochemical Properties and Antioxidant Activities of Aqueous Extract of Mistletoe Leaves (Tapinanthus bangwensis) Grown on Orange Trees. The FASEB Journal, 27:794-816.

30) Njoya HK, Chukwu EO, Okwuonu CU, Erifeta GO, 2018. Phytochemical, proximate and elemental analysis of the African mistletoe (Tapinanthus preussii) crude aqueous and ethanolic leaf extracts. Journal of Medicinal Plants Studies 6(6): 162-170.

31) NMA, 2020. Nigerian Meteorological Agency, Margaret Ekpo International Airport, Calabar.

32) North MK, Dalle Zotte A, Hoffman LC, 2018. The effects of quercetin supplementation on New Zealand white grower rabbit carcass and meat quality - A short communication. Meat Science 145: 363-366. https://doi.org/10.1016/j.meatsci.2018.07.014.

33) NRC (2012). Nutrient requirements of rabbits. National Research Council. 2nd Ed. National Academic Press, Washington, DC, USA.

34) Ogunmefun OT, Olatunji BP, Adarabioyo MI, 2015. Ethnomedicinal Survey on the Uses of Mistletoe in South-Western Nigeria. European Journal of Medicinal Plants 8(4): 224-230.

35) Olawoyin OO, Iso IE, 2007. Performance indices of rabbits fed Vernonia amygdalina leaf meal. Supplement. Tropical Journal of Animal Science 10 (1-2): 377-382.

36) Ologboho AS, Adejumo IO, Owoeye T, Akangbe E, 2017. Influence of mistletoe (Viscum album) leaf meal on growth performance, carcass characteristics and biochemical profile of broiler chickens. Food and Feed Research 44(2): 163 - 171.

37) Omoikhoje SO, Bamgbose AM, Aruna MB, Animashaun RA, 1996. Response of weaner rabbits to concentrate supplement with varying levels of Syndrella modiflora-forage. Pakistan Journal of Nutrition 5(6): 577-579.

38) Osadebe PO, Ukwueze SE, 2004. A comparative study of the phytochemical and antimicrobial properties of the Eastern Nigerian specie of African Mistletoe (Loranthus micranthus) sourced from different host trees. BioResearch 2(1):18-23. 
39) Ozung PO, Kennedy Oko OO, Agiang EA, Eburu PO, Evans EI, Ewa CE, 2017. Growth performance and apparent nutrient digestibility coefficients of weaned rabbits fed diets containing different forms of cocoa pod husk meal. Agriculture and Food Science Research 4(1): 8-19,

40) Para, P. A.; Ganguly, S.; Wakchaure, R.; Sharma, R.; Mahajan, T. \& Praveen, P. K. (2015). Rabbit has the potential of being a possible alternative to other meats as a protein source: A brief review. International Journal of Pharmacology and Biomedical Ressearch 2:17-19.

41) Paul and Southgate(1985). At water system of Energy Value Determination.

42) Simonová MP, Chrastinová L, Mojto J, Lauková A, Szábová R, Rafay J, 2010. Quality of rabbit meat and phyto-additives. Czech Journal of Food Science 28: 161-167.

43) Tizhe TD, Alonge SO, Aliyu RE, 2016. Mistletoe presence on five tree species of Samaru, area, Nigeria. African Journal of Plant Science 10(1): 16 -22.

44) Umarudeen AM, Magaji MG, 2020. Anxiolytic Mechanisms and Corticosterone-Attenuating effect of hydro-alcoholic leaf extract of Tapinanthus globiferus mistletoe growing on Azadirachta indica tree. Journal of Complementary and Alternative Medicine Reseasrch 10(1): 14-23. https://doi.org/10.9734/jocamr/2020/v10i130153.

45) Vaughan JG, Juddk PA 2003. The Oxford Book of Health Foods: A Comprehensive Guide to Natural Remedies. 1st Edition. Oxford University Press, New York, USA.

46) Volek Z, Bureš D, Uhlírová L 2018. Effect of dietary dehulled white lupine seed supplementation on the growth, carcass traits and chemical, physical and sensory meat quality parameters of growing-fattening rabbits. Meat Science 141: 50-56. https://doi.org/10.1016/j. meatsci.2018.03.013.

47) Yalçin S, Onbaşilar EE, Onbaşilar İ 2006. Effect of sex on carcass and meat characteristics of New Zealand White rabbits aged 11 weeks. Asian-Australian Journal of Animal Science 19:1212-1216. tps://doi.org/10.5713/ajas.2006.1212.

48) Zepeda-Bastida A, Ayala Martínez M, Soto Simental S. 2019. Carcass and meat quality of rabbits fed Tithonia tubaeformis weed. Revista Brasileira de Zootecnia 48:e20190074. 